\title{
О романе Владимира Набокова «Лолита»
}

\author{
ЭРЖЕБЕТ КАМАН \\ KÁMÁN Erzsébet, ELTE Keleti Szláv és Balti Tanszék, Budapest, Múzeum krt. 4/D, H-1088
}

\begin{abstract}
The critical reception of the novel "Lolita" today. Nabokov's novels and contemporary Russian prose trends: symbolism, avant-garde. Nabokov and western literature. Love, passion, cult of the female in Russian art in the early 20th century. The novel's child heroine. The novel's problems of form: the role of the narrator and the writer in the text of the novel. The English and Russian versions of the novel.

Keywords: novel, critical reception, symbolist prose, avant-garde prose, love, passion, female ideal, narrator, writer, novel text, portrayal of a child, the writer's bilingualism

«Легко проникнуть в мир Будды, но трудно проникнуть в мир демонов. (...) Каждого художника, который стремится к истине, добру, красоте как к главной цели своих исканий, неизбежно преследует желание прорваться в мучительный мир демонов»
\end{abstract}

(Kawabata Yasunari, Conférence de Stockholm, первод Норы Букс).

В 1999 г. отмечалось столетие со дня рождения Владимира Набокова. Его многочисленные читатели и неутомимые исследователи вновь и вновь обращаются к большому наследию писателя: к его уникальным романам и превосходной поэзии. Мнения исследователей разделяются, и уже существуют издания исследовательских работ о творчестве Набокова, озаглавленные «Pro et contra» (PC). За долгие годы, прошедшие со времени публикации стихов юного Набокова в конце 10-х годов, и вскоре, когда в 20-е годы один за другим стали выходить его романы, вызвавшие большой интерес, писать о его творчестве не переставали. Сделано многое, выяснена тесная связь произведений Набокова с духовными и художественными движениями XX в. в России и на Западе. Но отмечено и особое положение писателя Набокова, с детства в очень богатой семье окруженного английскими и французскими учителями и не умевшего писать по-русски (что заметил его отец), окончившего университет в Кембридже, жившего и работавшего в Германии, Франции, Соединенных Штатах Америки. Он был активным участником не только Серебряного века русской культуры начала XX в., на него (в силу его укорененности в традициях современной ему западной курьтуры) лег отсвет и Золотого века русской культуры времен Пушкина, Гоголя. Их творчество при всей «русскости» было связано с европей- 
ской культурой Просвещения и романтизма, с общественными, философскими и эстетическими исканиями драматичного начала XIX в. Набоков написал исследование о Гоголе, дающее, может быть, ключ к разгадке абсурда, обильно присутствующего в его романах. Он переводил русских поэтов на английский язык, перевел и «Евгения Онегина» Пушкина, прокомментировав в 4-х томах все ссылки, перифразы Пушкина, относившиеся к мировой литературе. (Отметим, что этот колоссальный филологический труд и сейчас в год 200-летнего пушкинского юбилея еще не раскрыт пушкинистами).

Сам Набоков был из поколенья «преодолевших символизм», как назвал В. М. Жирмунский $(1977,106)$ выступивших в начале XX в. поэтов-акмеистов: Н. Гумилева, А. Ахматову, О. Мандельштама. Тогда в России в литературу пришли различные группы, писатели и поэты, которые в поисках новых художественных решений пошли в других, чем поэты и писатели символизма, направлениях. Здесь были футуристы, заумники, молодые прозаики группы «Серапионовы братья» и не примкнувшие к группировкам такие художники слова, как Е. Замятин, И. Бабель, М. Булгаков и многие другие. Многое из этого богатого интеллектуального и художественного наследства спасла - в тяжелых условиях существовавшая в Европе - русская эмиграция. В ее среде тоже не в благополучной обстановке - в Берлине, Праге и Париже развивалось творчество Владимира Набокова. Писатель не прошел мимо каверзных коллизий своего века, в его романах мы видим трудные пути, блуждания человеческого духа в лабиринтах тирании, произвола и беззаконий. Но главная трудность для Набокова заключалась в том, что писавший более 20 лет по-русски, сорокалетний писатель перешел на английский язык. Он писал об этом:

Да, это был очень сложный переход. Моя личная трагедия, которая не может и не должна кого-либо касаться, это то, что мне пришлось отказаться от родного языка, от природной речи, от моего богатого, бесконечно богатого и послушного мне русского слога ради второстепенного сорта английского языка... По количеству слов английский гораздо богаче русского. Это особенно заметно в существительных и прилагательных. Довольно докучливая черта, свойственная русскому, - это недостаток, неточность и неуклюжесть технических терминов... С другой стороны, русский обладает превосходством в словах, передающих оттенки движения, жеста, чувства... Синтаксически английский исключительно гибкий инструмент, но русский можно ещё более тонко крутить и поворачивать (РС 160).

В предисловии к английскому изданию романа «Лолита» в 1967 г. Набоков объяснял «второстепенность» своего английского языка тем, что в его случае английский язык «лишен... всей той аппаратуры каверзного зеркала, черно-бархатного задника, подразумеваемых ассоциаций и традиций» (РС 89). Поскольку это важно для понимания романа, приведем еще слова писателя из его «Постскриптума»к русскому изданию этого романа в Америке:

Американскому читателю я так страстно твержу о превосходстве моего русского слога над моим слогом английским, что иной славист может и впрямь подумать, что 
мой перевод «Лолиты» во сто раз лучше оригинала. Меня же только мутит ныне от дребезжания моих ржавых русских струн... Но я пришел к некоторым общим заключениям по поводу взаимной переводимости двух изумительных языков... Телодвижения, ужимки, ландшафты, томления деревьев, запахи, дожди, тающие и переливчатые оттенки природы, всё нежно-человеческое (как ни странно!), а также всё мужицкое, грубое, сочно-похабное, выходит по-русски не хуже, если не лучше, чем поанглийски, но столь свойственные английскому тонкие недоговоренности, поэзия мысли, мгновенная перекличка между отвлеченнейшими понятиями, роение односложных эпитетов, всё это, а также всё относящееся к технике, модам, спорту, естественным наукам и противоестественным страстям - становится по-русски топорным... Эта невязка отражает основную разницу в историческом плане между зеленым русским литературным языком и зрелым, как лопающаяся по швам смоква, языком английским, между гениальным, но ещё недостаточно образованным, а иногда довольно безвкусным юношей и маститым гением, соединяющим в себе запасы пёстрого знания с полной свободой духа. Свобода духа! Всё дыхание человечества в этом сочетании слов (Набоков 1989, 358-359).

Высказывания Набокова сохранили свою актуальность.

Вопрос о художественном слове стоял в центре внимания и забот художников XX в.: в каком направлении можно было продолжить выполненную в начале века работу поэтов и писателей - символистов, создавших удивительно богатую лирику, наполнивших слово новыми абстрактными, интеллектуальными, духовными смыслами. Исследование отношений между искусством сецессиона и символизма, с одной стороны, и выступившими им на смену направлениями т.н. «исторического авангарда» еще далеко не закончено. В Венгрии в начале 1930-х годов поэт Дежё Костолани упрекал молодых поэтов в разрушении сложных изысканных форм, когда на смену ставшим привычными: «томлению смерти», «обморочной печали» пришли «телята» и «овины». Девиз молодых поэтов «простота и естественность», предупреждал Костолани, могут обернуться искусственностью и даже нарочитостью. «Художественная простота сложна, художественная естественность - нечто лукаво искусственное и хитрое», - писал Костолани (1971, 488-489). Дьюла Ийеш $(1964,368)$ в ответе Костолани подчеркнул, что речь идет не о «простоте улицы», что к этим менее изысканным формам перешли и молодые поэты во Франции (Элюар, Фоллен и другие), что от неточной рифмы «вспыхивает искренний порыв», звучит искренний, иногда хриплый голос человека.

Многие исследователи отмечали интеллектуальный характер романов Набокова и их связь с романами А. Белого. Однако набоковское преломление «мозговой игры», которую ведет Белый $(1981,14)$ со своими героями, - иное, все странные образы ментального мира человека, закрепленные в символах, в романах более молодого современника Белого - ближе метафоричности, характерной для прозы писателей авангарда. Философская насыщенность прозы Замятина, Олеши, новая образность по-иному раскрывали место человека в макро- и микромире, делали шаг к онтологии. В этом направлении шел и Вла- 
димир Набоков, что отметили и русские (Левин: РС 373), и английские критики (Rowe 1974) его романов.

Приведенные выше размышления Набокова о языке связаны главным образом с романом «Лолита». В небольшой статье, наверное, правильнее будет остановиться именно на этом романе, хотя тема его особенная: половое извращение, педофилия. Можно ли сказать, что писатель выбрал случайную тему? Говорит об исключительном случае? Мы постараемся показать, что за случаем он увидел важное для человеческой культуры явление: отношение к женщине, проблему культуры чувства XX в. Набоков подошел к этой трудной проблеме не с точки зрения биологии или психопатологии. Как художник он должен был в идивидуальном конкретном образе героя романа рассказать о его жизни, среде и в какой-то форме - более широко и о самом болезненном явлении, о его противоестественной страсти.

В одном из редких интервью, когда писателя спросили, не раздражает ли его, написавшего целую полку книг по-английски, из которых широко известна лишь «Лолита», что его зовут «мистер «Лолита»? Он ответил:

Нет, потому что «Лолита» - из моих любимиц. Это была самая трудная для меня книга - книга, в которой рассматривалась тема, такая чуждая, далекая от моей собственной эмоциональной жизни, что мне доставляло особенное удовольствие использовать мой комбинаторный талант, чтобы сделать ее реальной.

На вопрос: почему был написан роман, писатель ответил:

Потому что мне это было интересно. Да в конце концов, почему я написал любую из моих книг? Ради удовольствия, ради сложности. У меня нет социальной цели, нет нравственного учения, нет никаких общих идей, чтобы их рекламировать, я просто люблю составлять загадки с изящными решениями (РС 143-144).

Но в критической литературе о Набокове больше всего разногласий - именно в связи с этим романом, с его двумя главными героями: пишущим свои воспоминания Гумбертом Гумбертом и предметом его страсти. Следует отметить, что об этой 12-летней американской девочке, школьнице, давшей название роману, пишется меньше всего. Один из первых ценителей таланта Владимира Набокова, много писавшая о нем - Нина Берберова (писатель, критик, преподаватель в Принстонском университете) посвятила роману «Лолита» целую главу в своих воспоминаниях. Она считает, что эта книга «не умещается в своей обложке, ... годами живет с нами, меняя нас, меняя наше сознание». Набоков не имеет отношения к «нравоучительному хламу: «Что делать?» или «Кто виноват?». Его роман ироничен, но на

втором плане... мы видим книгу о двойнике... Гумберт Гумберт начинает превращаться в свою противоположность, когда он начинает выходить из ада желаний, преступлений и переходит по ту сторону жизни, где он не только может свободно желать гибели, но и искать и найти ее (Берберова: РС 298). 
Критик настолько высоко оценивает метаморфозу героя Набокова, что считает:

Старый мир, в котором мы родились (с веком наравне) ... только у Набокова получил смысл, потому что ему возвращен катарзис. Всё зло, весь ужас, все преступления вдруг оказались призрачными, и как в «Приглашении на казнь» Цинциннат, так и Гумберт Гумберт пошел наконец мимо всех декораций туда, где встало над ним «неподвижное солнце любви» (РС 296).

Последняя парафраза из стихотворения философа Владимира Соловьева $(1990,58)$ - основоположника и зачинателя русского символизма. Нина Берберова отмечает многочисленные параллели из мировой литературы, сопутствующие образу Гумберта Гумберта: мотивы из произведений Достоевского, По, Стерна, Стринберга, Сервантеса, Пушкина, Толстого, Гейне, Гоголя, Бодлера, Блока... Этой теме посвящена капитальная работа Карла Проффера (1968).

О героине романа сказано лишь, что «это 12-летняя девочка..., олицетворение прелести, очарования и женственности, но не невинности» (Берберова: РС 298) . Она - лишь предмет страсти героя.

В критической литературе о романах Набокова часто встречается замечание об автобиографичности многих его героев (Левинтон: РС 322 ).

Такой внимательный читатель, переводчик «Лолиты» с английского на венгерский язык, как Пал Бекеши $(1987,340)$ пишет в послесловии:

Помимо чуждости (ведь Гумберт Гумберт чужой в Америке. Интеллектуал французского происхождения, по языку и духу чужой в той среде) набоковские герои обладают другой особенностью, тем, что они уже чуть ли не равны их создателю».

К счастью, он тут же замечает, что в каждом романе Набокова можно заметить «точную моральную структуру. В 1966 г. в предисловии к английскому изданию романа «Отчаяние» (1936) Набоков писал (РС 61):

Я не в силах предусмотреть и предотвратить неизбежные попытки найти в змеевиках «Отчаяния» нечто от риторического яда, который я впрыснул в слог повествователя другого гораздо более позднего романа («Лолита», 1953-55. - Э. К.). Герберт и Гумберт сходны лишь в том смысле, в каком два дракона, нарисованные одним художником в разные периоды его жизни, напоминают друг друга. Оба они негодяи и психопаты, но всё же есть в раю зеленая аллея, где Гумберту позволено раз в год побродить в сумерках, Германа же Ад никогда не помилует.

В другом месте писатель назвал своего героя «человеком с навязчивой идеей» (РС 143), а в удвоении его имени - нечто, содержащее «много гнусного и много намека» (РС 151), что можно понять как некую маску, скрывающую его лицо.

Один русский исследователь высказал предположение, что английское произношение начала имени Гумберта — «хам-...» напоминает имя сына Ноя, насмеявшегося над отцом (хотя для того, чтобы 
почувствовать это, читателю нужно было бы знать оба языка!). В этом имени звучит и латинское umbra 'тень' (Долинин: РС 892). Михаэль Лонг $(1984,142)$ подчеркивает, что герой сознает свою извращенность, но его «необузданный рассказ об этом ... создает смущающее и увлекательное впечатление». Он называет роман «воздушной книгой, на чей путь воображение легко вступает, но и свободно его покидает».

В одном из новых исследований (Сендерович и Шварц 1999, 64) проблематика романа «Лолита» рассматривается «по ту сторону порнографии и морализма», без той двойственности, которая долгие десятилетия сопровождала читательские впечатления о романе. Авторы статьи стремились открыть в романе «метафизический план», характерный для романов Набокова вообще. Они увидели его в метаморфозах автора, идущего по лабиринту в поисках красоты. Согласно новому мироощущению, господствовавшему на рубеже XIX и XX в. и в начале XX в., жизнь человека должна была стать искусством, а искусство - жизнью. Образец этого они увидели в жизни Александра Блока. Герой - поэт проходит через мир соответствий - символов, принимающих на второй ступени демонический облик. На третьей ступени герой освобождается от наваждений и переживает катарзис. По мнению авторов этой статьи, эстетизированный конфликт переведен в романе «Лолита» «из космического плана в персоналистический». С авторами статьи во многом можно согласиться: в романе «Лолита» действительно поставлен вопрос о любви, красоте, блужданиях и заблуждениях, как и во всех больших романах XX в., в связи с трудными проблемами именно этого века. Но в одном я могла бы выразить свое несогласие с авторами статьи: с неразличением Гумберта Гумберта героя романа, повествователя и писателя Набокова, написавшего роман и создавшего и своего героя.

Писатели часто использовали такую непростую форму повествования, где вроде бы все возможности были предоставлены герою, его опыту, оценке, а у автора оставалось совсем немного возможностей поправить своего героя или дополнить его рассказ. В литературоведении эта форма получила название «повествования от первого лица» (Icherzählung). И не всегда избранный писателем герой был близок автору, как, например, Блум в романе Джойса «Улисс» или Крулль в романе Т. Манна «Записки Феликса Крулла...» или Назар Ильич в одноименном сборнике рассказов Зощенко. В силу художественного характера повествования у автора есть возможность выбрать такие факты, о которых мнение автора и героя расходятся, и тем или иным образом заявить о разном отношении к ним автора и героя. Может быть, именно тема о «тайном пороке», о котором редко говорится открыто, дала повод писателю - обратиться к этой форме и, не стесняя своего героя ни в чем, предоставить и ему случай высказаться откровенно. Но перед тем, как читатель прочтет записки героя, автор в роли «издателя» 
записок извещает читателя о том, что герой умер в тюрьме накануне суда над ним, а героиня умерла от родов (чего, в свою очередь, не знает герой записок). Свои записки Гумберт Гумберт начинает с пламенного признания в любви: «Лолита, свет моей жизни, огонь моих чресел!» (Набоков 1989, 22). Однако в рассказе о своей жизни: о двух браках, заключенных в полном безразличии, да и в отношениии к Лолите на протяжении длившихся три года любовных отношений Гумберт Гумберт никогда не скрывал насмешливого пренебрежительного отношения к женщине вообще. Еще в детстве, безоблачном и счастливом, на берегу Средиземного моря, в условиях праздничной жизни, флиртов и легких связей с женщинами, которые видел мальчик, он начал растить в себе особое чувство красоты. Без матери, одинокий среди стольких «нянек», он абсолютизировал свою первую еще детскую любовь (памятную каждому человеку!), выделив в ней мотив чувственности, не удовлетворенной в тех случайных, потрясших мальчика обстоятельствах. Со временем красота в его понимании получила особое преломление: это была не просто женская красота, а первое едва заметное проявление женской грации в еще не развившейся девочке. Гумберт Гумберт ценил в себе эту особую способность, свою чувствительность и чувственность. Наверное, не было случайным и его увлечение «проклятыми» французскими поэтами конца XIX в., где красота и чувственность нашли яркое проявление. В молодые годы он написал сравнительный анализ французской и английской поэзии того времени, нечто вроде учебника и книги для чтения. Позже мы не видим его за умственными занятиями, он целиком погружен в свою страсть к девочкам - «нимфеткам». Но страсть его имперсональна.

Ностальгия нашего времени - конца XX в. с его «массовой культурой», с культом безобразного поможет нам заметить это особенное чувственное отношение героя романа к женщине и ее красоте, зародившееся на рубеже XIX и XX вв. Оно стало заметным на фоне старых традиций. Воспетая в народных песнях красота невесты соседствовала с ужасным, подчиненным положением женщины в семье и насилием над ней и над несовершеннолетними девочками в деревне (Szenti 1999, 27-46). Женщина обеспеченных кругов была ограничена «детьми, кухней и церковью».

Повышенный интерес к женщине, воспетый искусством, казалось, был глобальным, так как высвободил жизненные силы и в природе. Мир в искусстве сецессиона был заплетен бурными лианами, и их бесконечные извивы символизировали некую полноту, избыток жизненных сил. Но воспевая силу любви, выраженную в безудержной чувственности, подчеркивая роль женщины, искусство начала XX в. «приглушало» нравственные критерии: человеческую личность, достоинство, самостоятельность женщины. Она становилась лишь объектом безмерного желания или символом непонятной демонической власти 
над мужчиной. Эта тенденция пронизала культурологические исследования, проникла в большую психологию и психиатрию, закрепившись не просто как естественное различие женщины и мужчины, а как их вечное противостояние и вражда.

Даже в освежающей атмосфере «Новых стихов» Эндре Ади (1954, 26), в гениальной лирике о большой любви поэта в «Псалмах Леде» (его ближайшей помощнице - по свидетельству интеллектуального окружения поэта в Париже) любовь изображалась как «кровавая свадьба», как схватка двух коршунов на опавших ржавых листьях в лесу. Здесь мы найдем мотивы, характерные для лирики символистов: и смертельную любовь - вражду, и трагическую мрачную картину умирающей природы.

Идеи Ницше повысили не только статус человека, но и его самомнение, заложив основу самоощущения человека начала века. Следует вспомнить, что в начале XX в. большим влиянием пользовался молодой венский философ Отто Вейнингер, чья книга «Пол и характер. Принципиальное исследование» выдержала десяток изданий и в 1909 г. была переведена на русский язык. Р. Дёринг-Смирнова (1999, 65-66) указала, каким авторитетом пользовалась она в России: А. Белый назвал ее «психологическим документом гениального юноши», о ней писали Розанов, Бердяев, ее мотивы заметны в лирике 3. Гиппиус, от нее отталкивался Б. Пастернак в романе «Доктор Живаго».

Итак, страсть Гумберта Гумберта имперсональна, его понимание судьбы Лолиты ущербно. Даже после трех лет поисков Лолиты, когда разлука с Лолитой обострила привязанность к ней, тоску по ней, когда в одиноком Гумберте Гумберте развилось (поверим ему!) чувство любви к Лолите, их новая и последняя встреча разочаровала героя и дала ему лишь материал для раздумий. Он видит «свою Лолиту» «безнадежно увядшей». Гумберт Гумберт в ироническом тоне говорит о «её младенце», «уже мечтающем стать, небось, большим заправилой и выйти в отставку в 2020-м году». Но ведь реальная жизнь девочки, её планы никогда не были интересны для него. Теперь Лолита - «лишь легчайшее фиалковое веяние, листопадное эхо той нимфетки, на которую я наваливался с такими криками в прошлом; эхо на краю красного оврага с далеким лесом под белесым небом, с бурыми листьями, запрудившими ручей, с одним последним сверчком в сухом бурьяне» (Набоков 1989, 315). Эта страничка «лирики» Гумберт Гумберта вписывается а рамки эстетики начала XX в. Выискивание красоты и только красоты неуместно в обстановке нищенского дома Лолиты. В этой непридуманной жизни нет места красоте, но есть дружба Лолиты с мужем - ее опорой и с его товарищем - тоже калекой далекой войны. И наряженный в шелковое белье, благоухающий Гумберт Гумберт невыгодно для него противопоставлен скромному молчаливому (стесняющемуся своей глухоты), но ведущему себя со спокойным достоинством мужу Лолиты. 
Кстати, Гумберт Гумберт часто употребляет высокие слова при описании своих эротических удовольствий. После первого удовольствия он раскрывает свое самочувствие с помощью характерного и стандартного для фрейдизма описания: «День медленно протекал, молчаливый и спелый, и высокие, налитые соком деревья, казалось, были посвящены в тайну» (там же, 80). Писатель обращает наше внимание на непосильные для незрелой девочки частые наслаждения взрослого мужчины. Он рисует сцену оскорбительной униженности, которую испытывает Лолита, «доодеваясь в машине», после сцены соития «на природе», на лесной поляне под любопытными взглядами гуляющих детей и их мамаши. Писатель не забыл напомнить, как плакала Лолита по ночам: «её всхлипывания ночью», «каждой, каждой ночью, ... как только я притворялся, что сплю» (там же, 202), как ни разу не удалось Гумберту Гумберту вызвать в ней ответное чувство наслаждения.

В их долгих путушествиях по стране Гумберт Гумберт старался лишь развлечь Лолиту, выбирая для оторванной от школы девочки лишь туристические достопримечательности. Описание природы, городов Америки Набоков «подарил» своему герою. Он писал:

Я приехал в Америку в 1940 г. и решил стать американским гражданином и сделать Америку своим домом... Так случилось, что я сразу же встретился с самым лучшим в Америке, с её богатой интеллектуальной жизнью и её непринужденной добродушной атмосферой (РС 152).

Но любить и понимать природу Гумберт Гумберт научился не сразу, его чувства вторичны, сначала он увидел облака, как у Лорена, сумрачное небо, как у Греко. Лолите же передать он ничего так и не смог.

В образе играющей в тенис девочки он не разглядел грации ребенка, играющего не для победы, а для самой игры:

Несмотря на малый рост, она покрывала всю свою половину площадки, с необыкновенной легкостью, однажды вступив в ритм обмена и покуда могла этим ритмом управлять, но всякая резкая атака, всякая внезапная перемена приводили её в состояние полной беспомощности... До того бесплодными оказываличь её грация и блеск (Набоков 1989, 266).

После этого скорее авторского описания мы читаем замечание Гумберта Гумберта, который считает «за финту нимфетки веселое равнодушие к исходу игры» (там же, 266).

В романе есть и другие сцены, где можно видеть авторские поправки в тексте рассказчика. Это сцена, где Гумберт Гумберт с формальной вежливостью беседует с отцом подружки, пришедшей в гости к Лолите. Он видит лишь, как некрасивая девочка доверчиво прильнула и ласкается к отцу, но не выясняет, почему Лолита вышла из комнаты. Принуждая Лолиту к сожительству, он прямо грозит ей в случае непослушания исправительной колонией или зачитывает из популярной брошюрки ставшие расхожимы фрейдистские поучения о 
роли отца. В записках Гумберта Гумберта есть строки о его страданиях, когда занятая уроками Лолита отталкивает его:

Она смотрела на меня взглядом, похожим на серый мохнатый вопросительный знак, говорящий с недоверием, с раздражением: «Как - уже опять?» и - «Ах, отстань от меня, старый павиан!» ... «Христа ради, прошу тебя, отстань от меня наконец!» (Там же, 120-121).

Образ Лолиты в романе не идеализирован. Грубость подростка связана с попыткой содать свое собственное мнение, а не с таинственными поступками нимфетки. Набоков не скрывает и ограниченного запаса культуры, которым обладала и ее мать, стандартов поведения, против которых восставала Лолита, как и любой подросток. Сексуальность, пробуждающийся половой инстинкт всегда были трудны и для подростка, и для родителей, и для общества. Положение Лолиты еще труднее, так как от матери, ничего другого не знающей кроме строгости и наказания, помощи ждать нечего, а «отчим» воспользовался доверием девочки в своих целях. А ведь Лолиту мучает сознание неправильности своего поступка в лагере, и она хочет рассказать, выяснить для себя правильность поведения в этом сложном деле. Идеал кинозвезды в Голливуде завел Лолиту в сети негодяев, принуждавших ее сниматься в порнографических фильмах. Но она все же встала на ноги, какие бы бедные возможности не предоставляла ей судьба. Ее письмо разительно отличается от надуманного и все же трафаретного письма матери: «Дорогой Папа! Как поживаешь? Я замужем. Я жду ребенка... Я узнала много печали и лишений...» (Там же, 303). Дочка Лолиты не смогла родиться. Ее молодая мать не успела за свою короткую жизнь собрать физические и духовные силы, всю любовь к ребенку и помочь ему появиться на свет. Сыграло ли тут роль ее покалеченное детство? В какой-то мере - да.

Набокова интересовало мнение читателей, о самых крайних отзывах он знал, когда родители запрещали своим дочкам - студенткам посещать лекции «мистера Набокова» (Field 1977, 277). Но редко вступавший в спор и редко помогающий читателям, он говорил, что в книге присутствует «ее нервная система», и в качестве таких нервных узлов (как бы аксиологических ориентиров в эстетической, интеллектуальной системе мотивов и образов) он назвал «учтивого Таксовича», список учеников школы, где училась Лолита в ее «догумбертовском детстве», Лолита, подступающая к подаркам Гумберта Гумберта или играющая в мяч, фотопортреты в комнате педераста Годена, парикмахер в городке Касбим и голоса играющих детей в городке, звуки которых поднимались вверх на горную тропу, где стоял его герой. Что же это за система? Это ряд мужских характеров. Здесь и русский полковник шофер такси в Париже, которого Гумберт Гумберт со злости прозвал Таксовичем, который оградил жену Гумберта Гумберта от кулаков мужа (вспомним его мечты утопить, одурманить свою вторую жену). 
И парикмахер, с гордостью рассказывающий об успехах сына, умершего несколько лет назад, с чем отец не может примириться... С другой стороны, это портретная галерея знаменитых художников, писателей, композиторов со склонностями педерастов. Нужно сказать, что все эти отцы никак не вписываются в фрейдистскую «норму». Рядом с ними важные эпизоды и жизни Лолиты, и игры детей, в которых она не могла принять участие.

Раскаяние Гумберта Гумберта искренне, он сознает себя чудовищем по отношению к Лолите, даже идет к священнику, чтобы облегчить свою совесть. Но вывод его таков (он отлил его в форму стиха, чтобы подчеркнуть его значимость):

Так пошлиною нравственности ты

Обложено в нас, чувство красоты

(Набоков 1989, 321).

Итак, красота - по ту сторону добра и зла? Значит любовь остается лишь страстью? И вся красота, вся сложность отношений женщины и мужчины - это лишь чуждая и тягостная обуза для любви? Оставим спор с Гумбертом Гумбертом, мы его выслушали до конца.

Набоков (РС 57) достаточно ясно прокомментировал свое категорическое утверждение «о совершенной мифонепроницаемости» его книг. Но он отчетливо сознавал и принципиально спорный, теоретический характер своих книг, когда утверждал: «Я пишу главным образом для художников - товарищей и последователей» (РС 165). Эстетическое наслаждение писатель понимает «как особое состояние, при котором чувствуешь себя - как-то, где-то, в чем-то - связанным с другими формами бытия, где искусство (т.е. любознательность, нежность, доброта, стройность, восторг) есть норма» (РС 86). И хотя писатель сказал это о романе «Лолита» в послесловии к американскому изданию в 1958 г., слова его о характере эстетики, наверное, не только можно, но и нужно понимать шире. В интервью, опубликованном в сборнике «Твердые мнения» в 1973 г., Набоков (РС 157) писал:

Писатель - творец должен внимательно изучать труды своих конкурентов, в том числе и Всевышнего. Он должен обладать врожденной способностью не только воссоздавать, но и пересоздавать мир. Чтобы делать это как следует, избегая двойного труда, художник должен знать мир. Воображение без знания ведет лишь на задворки примитивного искусства, к каракулям рубенка на заборе или речи безумца на рынке. Искусство не бывает простым.

Среди поздних стихотворений Набокова есть и такое «Какое сделал я дурное дело?» По сути это пародия на стихотворение Пастернака «Нобелевская премия», где говорится о гонениях на писателя после публикации романа «Доктор Живаго.» В «Постскриптуме» к изданию «Лолиты» на русском языке Набоков не скрыл пренебрежительной оценки романа Пастернака в противовес высокой оценке его поэзии. Он пишет о «лирическом докторе с лубочно-мистическими позывами, 
мещанскими оборотами речи и чаровницей из Чарской, который принес советскому правительству столько добротной иностранной валюты» (Набоков 1989, 701).

Мы знаем, что и Анна Ахматова «не благоволила» к роману «Доктор Живаго» (Ehrlich 1998, 701). Многие исследователи отмечали сложность отношений двух писателей, общие черты в их творчестве, а также отталкивание друг от друга. Ю. Левин (РС 366) заметил в «описательных и философствующих» фрагментах „Дара“ и „Других берегов“ ... несомненный отпечаток усвоения ранней прозы и стихов Пастернака».

Вопрос о сходном и различном в творчестве этих больших художников-современников представляет большой интерес не только в историко-литературном, но и в теоретическом плане с точки зрения дальнейшего развития художественной прозы - еще дальше - уже от поэтики авангарда. И здесь пути Набокова и Пастернака далеко расходятся. Испытавший «второе рождение» (поэтическое, конечно), Пастернак в одноименном сборнике начала 30 -х годов впал в соблазн «неслыханной простоты» (стилистической, конечно). Его известный роман, написанный неровно, несет на себе признаки обоих периодов его творческой деятельности.

Романы Набокова - значительнейшая часть его творческого наследия. Они уникальны, и хотя несут на себе печать руки одного мастера, разнятся каждый и по своей проблематике, новой конструкции и стилю. В анализе романа «Лолита» мы наметили лишь - как бы пунктиром - основные моменты в коллизии романа, основные вехи в жизни героев. Набоков самым тщательным образом работал над английским и русским текстом романа. Его английский Гумберт Гумберт более сдержан, герой в русском тексте более склонен к тому, чтобы в поэтических описаниях использовать метафоры, а ритмические части текста оформить как стихотворный текст. Это, конечно, вносит новые оттенки в характер Гумберта Гумберта.

В стихотворении «Какое сделал я дурное дело?» Набоков $(1990,71)$ курсивом выделяет строки:

$$
\begin{aligned}
& \text { И я ли развратитель и злодей, } \\
& \text { Я, заставляющий мечтать мир целый } \\
& \text { О бедной девочке моей? }
\end{aligned}
$$

Стихотворение заканчивается на пронзительной лирической ноте:

$$
\begin{aligned}
& \text { Но как забавно, что в конце абзаца, } \\
& \text { Корректору и веку вопреки, } \\
& \text { Тень русской ветки будет колебаться } \\
& \text { На мраморе моей руки. }
\end{aligned}
$$

\section{Литература}

АЛЕКСАНДРОв Вл. Е. 1997 - «Потусторонность» в «Даре» Набокова (1986): РС.

БЕЛЫЙ $A .1981$ - «Петербург». Москва

БЕРБЕРОвА Нина 1997 - Набоков и его «Лолита» (1959): РС.

БукС Нора 1997 - Двое игроков за одной доской (1993): РС.

Studia Slavica Hung. 46, 2001 
ДЁРИнг-СмиРновА Р. 1999 - Пастернак и Вейнингер: Новое литературное обозрение № 3.

Долинин А. 1991 - Предисловие к роману «Лолита». Москва

ЖиРмунСкий В. М. 1977 - Теория литературы. Поэтика. Стилистика. Ленинград

ЛЕвин Ю. 1997 - Заметки о «Машеньке» Набокова (1985): РС.

МЕдАРич M. 1997 - Владимир Набоков и роман ХХ столетия ( 1990): РС.

НАБоков Владимир. «Лолита». Москва 1989.

НАБоков В. Стихотворения и поэмы. Москва 1991.

Набоков Владимир. Pro et contra. Санкт-Петербург 1997 (= РC).

ПАСТЕРНАК Б. 1989 - Собрание сочинений в 5 томах, 2. Москва.

ПРОФФЕР К. 1968 - Цит. по: STEINER G., Extraterritorial Papers of Literature and Language Revolution. London 1972.

СЕНДЕРОВИЧ С., ШВАРЦ Е. 1999 - «Лолита». По ту сторону порнографии и морализма: «Литературное обозрение» № 2

СоловьЕв Вл. 1999 - Стихотворения. Проза. Письма. Москва.

ADY Endre Összes versei. Budapest 1954.

BÉKÉSI Pál, Utószó: Vladimir Nabokov „Lolita”. Budapest 1987.

EHRLICH Victor, Ахматова в XX веке: Revue des Études Slaves 1998, 699-704.

FIELD Andrew, Nabokov. His Life in Part. London 1977.

ILLYÉS Gyula, Iránytüvel, 1. Budapest 1964.

KosZTolánYi Dezsö, Nyelv és lélek. Budapest 1971.

LONG Michael, Marvell. Nabokov. Childhood and Arcadia. Oxford 1984.

NABOKOV Vladimir, Lolita. London 1980.

ROWE W. W. 1974 - Nabokov's Deceptive World. New York.

SZENTI Tibor 1999 — A nők társadalmi és szexuális kiszolgáltatottsága a magyar feudalizmus utolsó másfélszáz évében: Hagyományos női szerepek. Nők populáris kultúrában és a folklórban. Budapest. 